\title{
Pengaruh Suhu dan Waktu Pengeringan Terhadap Sifat Kimia dan Sensori Teh Celup Herbal Daun Putri Malu (Mimosa pudica Linn.)
}

\section{The Effect of Time and Drying Temperature on The Chemical and Sensory Properties of Herbal Tea Bag of Mimosa pudica Linn. Leaves}

\author{
Elia Agatha Christiani ${ }^{1}$, I Nengah Kencana Putra ${ }^{1 *}$, I Putu Suparthana ${ }^{1}$ \\ Program Studi Teknologi Pangan, Fakultas Teknologi Pertanian, Universitas Udayana \\ Kampus Bukit Jimbaran, Badung-Bali \\ *Penulis korespondensi: I Nengah Kencana, Email: nengahkencana@unud.ac.id
}

\begin{abstract}
The objective of this study was to know the effect of time and drying temperature on the chemical and sensory properties of herbal tea bag made from Mimosa pudica Linn. leaves and to know the right time and drying temperature to get the best chemical and sensory properties of herbal tea bag of Mimosa pudica Linn. leaves. This research used a Completely Randomized Design with two factors i.e. drying temperature $\left(40^{\circ} \mathrm{C}, 50^{\circ} \mathrm{C}\right.$, and $\left.60^{\circ} \mathrm{C}\right)$ and drying time $(110$, 130, and 150 minutes). All of the treatments were repeated two times to obtain 18 units of experiments. The data obtained were analyzed by analysis of variance (ANOVA) and if the treatment had a significant effect, then it was followed by The Duncan Multiple Range Test (DMRT). The results showed that the interaction of time and drying temperature had a significant effect $(\mathrm{P}<0,05)$ on total flavonoids, but no significant effect $(\mathrm{P}>0,05)$ on the moisture and extract content, total phenolics, and $\mathrm{IC}_{50}$ valued. The drying temperature had a significant effect on the moisture content and $\mathrm{IC}_{50}$ valued, while the time and drying temperature had a significant effect on the extract content and taste (scoring test). The results showed that the drying temperature of $50^{\circ} \mathrm{C}$ for 110 minutes was the best treatment, where the herbal tea produced had a criteria: moisture content $6.50 \%$; extract content $14.70 \%$; total phenolics $25.19 \mathrm{mg}$ GAE/g dry weight; total flavonoids $16.07 \mathrm{mg}$ QE/g dry weight; $\mathrm{IC}_{50}$ valued $74.45 \mathrm{ppm}$; the color, flavor, and taste were slightly liked; an overall acceptance neutral; and the taste was slightly bitter.
\end{abstract}

Keywords: Mimosa pudica, herbal tea bag, drying temperature

\section{PENDAHULUAN}

Putri malu (Mimosa pudica Linn.) merupakan tanaman liar sejenis rumput yang termasuk ke dalam famili fabaceae. Ciri khas dari tanaman ini yaitu daun yang akan menutup dengan sendirinya ketika menerima rangsangan dan membuka kembali setelah beberapa lama (sensitive plant). Zhang et al. (2011) menyebutkan bahwa seluruh bagian tanaman putri malu mengandung senyawa antioksidan namun senyawa antioksidan tertinggi ditemukan pada daunnya dengan total fenol sebesar 9,87 $\pm 0,07 \mathrm{mg} / \mathrm{g}$ dan total flavonoid sebesar $0,81 \pm 0,02 \mathrm{mg} / \mathrm{g}$.
Antioksidan adalah senyawa yang mampu menghambat laju oksidasi molekul lain atau menetralisir radikal bebas (Fajriah et al., 2007). Hasil skrining fitokimia simplisia ekstrak putri malu menunjukkan adanya senyawa antioksidan seperti terpenoid, flavonoid, glikosida, alkaloid, kuinon, fenol, tanin, saponin, dan kumarin (Mohan et al., 2015). Ekstrak herba putri malu mempunyai khasiat sebagai transquilizer (penenang), ekspektoran (peluruh dahak), diuretik (peluruh air seni), antitusif (antibatuk), antipiretik (penurun panas), dan antiradang. Pemanfaatannya untuk obat dapat dilakukan dengan cara diminum 
maupun sebagai obat luar (Muhammad et al., 2016).

Berdasarkan komposisi komponen bioaktif dan senyawa antioksidan yang dikandungnya menunjukkan bahwa daun putri malu memiliki potensi besar untuk dimanfaatkan sebagai pangan fungsional seperti teh herbal. Teh yang dibuat selain dari daun teh disebut dengan teh herbal. Teh herbal adalah minuman yang berkhasiat untuk kesehatan. Teh herbal terbuat dari bebungaan, bebijian, dedaunan, atau akar dari beragam tanaman. Teh herbal dikonsumsi layaknya minuman teh, diseduh, dan disajikan seperti biasa. Teh herbal tersedia dalam kemasan kaleng, kantong teh, atau teh herbal siap minum dalam kemasan kotak. Teh celup merupakan olahan teh yang dikemas menggunakan kantong teh untuk sekali hidangan dengan mencelupkannya dalam air panas di gelas atau cangkir sehingga penggunaannya dinilai lebih praktis (Yudana, 2004). Jika ditinjau dari peran penting teh herbal bagi kesehatan, maka diperlukan metode pengolahan teh herbal yang tepat untuk menghasilkan karakteristik teh yang baik terutama pada penggunaan suhu dan waktu saat pengeringan.

Pengeringan merupakan tahapan pokok dalam pembuatan teh. Pengeringan bertujuan untuk mengurangi kadar air dalam daun teh, sehingga teh menjadi lebih awet dan lebih praktis untuk disimpan. Beberapa keuntungan pengeringan, yaitu memperpanjang umur simpan, meminimalisir penurunan mutu serta memunculkan aroma yang khas pada bahan. Lutony dan Rahmayanti (1994) menyatakan bahwa ketebalan jenis bahan mempengaruhi proses pengeringan simplisia. Semakin tipis jenis bahan yang digunakan, maka proses pengeringannya akan berjalan cepat karena kadar air yang terkandung dalam bahan sedikit.

Menurut Departemen Kesehatan RI (1985) herbal dapat dikeringkan pada suhu $30^{\circ} \mathrm{C}-90^{\circ} \mathrm{C}$, tetapi suhu terbaik tidak melebihi $60^{\circ} \mathrm{C}$. Penelitian yang dilakukan oleh Angraiyati dan Hamzah (2017) untuk mengetahui aktivitas antioksidan teh herbal daun pandan wangi (Pandanus amarylifolius Roxb.,) berdasarkan lama pengeringan $110,130,150,170$ dan 190 menit dengan suhu $50^{\circ} \mathrm{C}$ menyebutkan bahwa suhu $50^{\circ} \mathrm{C}$ dengan lama pengeringan 150 menit menghasilkan teh herbal daun pandan wangi dengan aktivitas antioksidan tertinggi. Hal ini serupa dengan penelitian yang dilakukan oleh Fitriana (2017) untuk menguji mutu teh herbal daun keji beling dengan perlakuan lama pengeringan 120, 150, 180 dan 210 menit dengan suhu $50^{\circ} \mathrm{C}$ yang menghasilkan aktivitas antioksidan tertinggi pada perlakuan lama pengeringan 150 menit.

Pengeringan juga berpengaruh terhadap seduhan teh herbal yang dihasilkan seperti warna, aroma, dan rasa. Fitriana et al. (2017) menyebutkan bahwa waktu pengeringan yang semakin lama dapat menyebabkan pigmen warna yang terdapat pada daun keji beling terdegradasi sehingga warna teh yang dihasilkan semakin memudar. Selain itu, pengeringan juga dapat menyebabkan senyawa volatil dan tanin yang ada pada bahan terdegradasi dan mengalami kerusakan sehingga berpengaruh terhadap aroma dan rasa teh herbal yang dihasilkan. Daun pandan wangi dan daun keji beling dianggap memiliki morfologi daun dengan 
ketebalan yang hampir serupa dengan daun putri malu sehingga digunakan sebagai pembanding. Karena tanaman putri malu memiliki komponen bioaktif yang cukup tinggi, maka diperlukan penelitian tentang pengaruh suhu dan waktu pengeringan dalam pembuatan teh celup herbal daun putri malu. Penelitian ini bertujuan untuk mengetahui pengaruh suhu dan waktu pengeringan terhadap sifat kimia dan sensori teh celup herbal daun putri malu dan untuk menentukan suhu dan waktu pengeringan yang tepat untuk menghasilkan teh celup herbal daun putri malu dengan sifat kimia dan sensori terbaik.

\section{METODE PENELITIAN}

\section{Tempat dan Waktu}

Penelitian dilaksanakan di Laboratorium Pengolahan Pangan dan Laboratorium Analisis Pangan, Fakultas Teknologi Pertanian, Universitas Udayana. Waktu penelitian berlangsung dari bulan Agustus sampai September 2020.

\section{Bahan dan Alat}

Bahan yang digunakan dalam penelitian ini yaitu daun putri malu muda satu hingga delapan tingkatan di bawah pucuk daun dengan kriteria berwarna hijau muda dan batang hijau kemerahan yang diperoleh di persawahan Cekomaria Denpasar Utara, metanol (Merck), aquades, standar kuersetin (Sigma), asam galat (Sigma), DPPH (Sigma Aldrich), reagen Folin-Ciocalteau (Merck), $\mathrm{Na}_{2} \mathrm{CO}_{3}$ (Merck), $\mathrm{AlCl}_{3} .6 \mathrm{H}_{2} \mathrm{O}$ (Merck), kertas saring Whatman no 1, paper tea bag food grade, aluminium foil, dan kertas label.

Alat yang digunakan dalam penelitian ini adalah kompor, dandang, baskom, oven, loyang, blender, ayakan 40 mesh, kuas, rotary shaker, spektrofotometer (Genesys 10S UV-Vis), timbangan analitik (Shimadzu ATY224), vortex, pipet tetes, pipet volume, pipet mikro, tabung reaksi, rak tabung reaksi, spatula, corong, labu ukur, gelas beaker, gelas ukur, erlenmeyer, botol amber, cawan alumunium, pinset, spatula, kuvet, dan desikator.

\section{Rancangan Percobaan}

Rancangan yang digunakan pada penelitian ini adalah Rancangan Acak Lengkap (RAL) pola faktorial yang terdiri dari dua faktor yaitu suhu dan waktu pengeringan. Faktor pertama yaitu suhu pengeringan dengan tiga taraf perlakuan yakni $40^{\circ} \mathrm{C}(\mathrm{T} 1), 50^{\circ} \mathrm{C}(\mathrm{T} 2)$, dan $60^{\circ} \mathrm{C}(\mathrm{T} 3)$. Faktor kedua yaitu waktu pengeringan (W) dengan tiga taraf perlakuan yakni 110 menit (W1), 130 menit (W2), dan 150 menit (W3). Kedua faktor tersebut dikombinasikan menjadi (T1W1), (T1W2), (T1W3), (T2W1), (T2W2), (T2W3), (T3W1), (T3W2), (T3W3) dan diulang sebanyak 2 kali sehingga diperoleh 18 unit percobaan. Data yang diperoleh dianalisis dengan sidik ragam dan dilanjutkan dengan uji jarak berganda Duncan untuk perlakuan yang berpengaruh nyata (Gomez dan Gomez, 1995).

\section{Pelaksanaan Penelitian.}

\section{Pembuatan Teh Celup Herbal Daun Putri Malu}

Penelitian ini diawali dengan melakukan pemetikan daun putri malu muda yaitu satu hingga delapan tingkatan di bawah pucuk daun dengan kriteria berwarna hijau muda dan batang hijau kemerahan, lalu dilakukan sortasi meliputi kesegaran daun, keutuhan daun, dan tidak terdapat bercak-bercak. Selanjutnya, dilakukan trimming 
untuk memisahkan daun putri malu dengan tangkainya dan dicuci dengan air mengalir kemudian ditiriskan.

Proses selanjutnya yaitu proses pelayuan dengan menggunakan metode steaming sesuai dengan yang dikerjakan oleh Topuz et al. (2014) dimana sampel yang telah dipisahkan batangnya dikukus dengan suhu $100^{\circ} \mathrm{C}$ selama 90 detik lalu daun didinginkan selama 5 menit. Daun putri malu kemudian dikeringkan menggunakan oven pada suhu $40^{\circ} \mathrm{C}, 50^{\circ} \mathrm{C}$, dan $60^{\circ} \mathrm{C}$ dengan waktu 110 menit, 130 menit, dan 150 menit. Setelah kering, dilakukan penggilingan menggunakan blender hingga halus, lalu dilakukan pengayakan dengan ayakan berukuran 40 mesh. Bubuk teh herbal daun putri malu kemudian dijadikan filtrat untuk dianalisis secara kimia dan sisanya dikemas ke dalam kantong teh celup berukuran 5,7 $\mathrm{cm} \times 5,2$ $\mathrm{cm}$. Masing-masing kantong teh celup berisi 2 gram serbuk teh herbal daun putri malu.

\section{Proses Pembuatan Filtrat Teh Celup Herbal Daun Putri Malu}

Bubuk teh daun putri malu sebanyak 1 gram dilarutkan dengan $50 \mathrm{ml}$ metanol $80 \%$, kemudian di-shaker dengan menggunakan rotary shaker selama 1 jam pada suhu ruang. Selanjutnya, sampel disaring dengan menggunakan kertas saring Whatman no 1. Filtrat disimpan dalam botol amber pada suhu $4^{\circ} \mathrm{C}$, kemudian dianalisis total fenol, total flavonoid, dan aktivitas antioksidan (Ghasemzadeh et al., 2012).

\section{Pembuatan Seduhan Teh untuk Uji Sensori}

Satu kantong teh celup herbal daun putri malu dimasukkan ke dalam gelas, kemudian ditambahkan air bersuhu $80^{\circ} \mathrm{C}$ sebanyak $100 \mathrm{ml}$ dan diseduh selama 3 menit. Dalam waktu 3 menit, kantong teh celup digerakkan naik turun sebanyak 10 kali dalam air. Setelah itu, kantong teh celup dikeluarkan dari larutan dan larutan dibiarkan sampai mencapai suhu kamar. Larutan diuji secara sensori (Badan Standar Nasional, 1996).

\section{Parameter yang diamati}

Parameter yang diamati pada penelitian ini adalah kadar air dengan metode thermogravimetri (AOAC, 2005), kadar ekstrak dalam air dengan metode thermogravimetri (Departemen Kesehatan RI, 2000), total fenol dengan metode FolinCiocalteu (Garcia et al., 2007), total flavonoid dengan metode spektrofotometri (Guntarti et al., 2017), aktivitas antioksidan berdasarkan nilai $\mathrm{IC}_{50}$ dengan metode DPPH (Hanani et al., 2005), serta evaluasi sensori meliputi: warna, aroma, rasa, dan penerimaan keseluruhan terhadap seduhan teh celup herbal daun putri malu (Soekarto, 1990).

\section{HASIL DAN PEMBAHASAN}

\section{Kadar Air}

Hasil sidik ragam menunjukkan bahwa interaksi antara suhu dan waktu pengeringan tidak berpengaruh nyata $(\mathrm{P}>0,05)$ terhadap kadar air teh celup herbal daun putri malu. Suhu pengeringan berpengaruh nyata $(\mathrm{P}<0,05)$ terhadap kadar air teh celup herbal daun putri malu sedangkan waktu pengeringan tidak berpengaruh nyata $(\mathrm{P}>0,05)$. Nilai rata-rata kadar air (\%) teh celup herbal daun putri malu pada perlakuan suhu dan waktu pengeringan dapat dilihat pada Tabel 1 . 
Tabel 1. Pengaruh suhu dan waktu pengeringan terhadap nilai rata-rata kadar air (\%) teh celup herbal daun putri malu

\begin{tabular}{cccc}
\hline \multirow{2}{*}{ Suhu Pengeringan } & \multicolumn{3}{c}{ Waktu Pengeringan } \\
\cline { 2 - 4 } & 110 menit & 130 menit & 150 menit \\
\hline \multirow{2}{*}{$40^{\circ} \mathrm{C}$} & $9,25 \pm 0,35 \mathrm{a}$ & $8,75 \pm 0,35 \mathrm{a}$ & $7,00 \pm 1,41 \mathrm{a}$ \\
& $(\mathrm{a})$ & $(\mathrm{a})$ & $(\mathrm{a})$ \\
$50^{\circ} \mathrm{C}$ & $6,50 \pm 1,41 \mathrm{a}$ & $6,00 \pm 0,00 \mathrm{a}$ & $5,50 \pm 0,00 \mathrm{a}$ \\
& $(\mathrm{ab})$ & $(\mathrm{ab})$ & $(\mathrm{ab})$ \\
$60^{\circ} \mathrm{C}$ & $4,75 \pm 0,35 \mathrm{a}$ & $4,00 \pm 2,12 \mathrm{a}$ & $3,50 \pm 0,71 \mathrm{a}$ \\
& $(\mathrm{b})$ & $(\mathrm{b})$ & $(\mathrm{b})$ \\
\hline
\end{tabular}

Keterangan : Nilai rata-rata \pm standar deviasi $(\mathrm{n}=2)$. Huruf yang sama di belakang nilai rata-rata pada baris yang sama atau di bawah nilai rata-rata pada kolom yang sama menunjukkan perlakuan berbeda tidak nyata $(\mathrm{P}>0,05)$

Hasil penelitian menunjukkan bahwa kadar air tertinggi diperoleh pada perlakuan suhu pengeringan $40^{\circ} \mathrm{C}$ selama 110 menit dengan nilai rata-rata sebesar 9,25\%, sedangkan kadar air terendah diperoleh pada perlakuan suhu pengeringan $60^{\circ} \mathrm{C}$ selama 150 menit dengan nilai rata-rata sebesar 3,50\%. Berdasarkan nilai rata-rata kadar air yang diperoleh, semakin tinggi suhu pengeringan maka semakin rendah kadar air yang dihasilkan. Penelitian yang dilakukan oleh Patin et al. (2018) mengenai kadar air teh daun sambiloto pada perlakuan suhu pengeringan $50^{\circ} \mathrm{C}, 55^{\circ} \mathrm{C}$, $60^{\circ} \mathrm{C}, 65^{\circ} \mathrm{C}$ dan $70^{\circ} \mathrm{C}$ juga menunjukkan hasil yang serupa. Semakin tinggi suhu pengeringan yang dilakukan maka semakin rendah kadar air yang dihasilkan karena penguapan air pada bahan semakin tinggi.

Menurut Winarsi (2011), semakin tinggi suhu udara pengering yang digunakan pada pengering oven, maka makin besar energi panas yang dibawa udara sehingga makin banyak jumlah massa cairan yang diuapkan dari permukaan bahan yang dikeringkan. Kemampuan bahan untuk melepaskan air dari permukaannya juga akan semakin besar dengan meningkatnya suhu udara pengering yang digunakan. Rendahnya kadar air pada perlakuan suhu pengeringan $60^{\circ} \mathrm{C}$ disebabkan oleh tingginya suhu udara pengering sehingga penguapan air pada bahan meningkat. Kadar air yang diperoleh dari penelitian ini pada perlakuan suhu pengeringan $50^{\circ} \mathrm{C}$ dan $60^{\circ} \mathrm{C}$ telah memenuhi standar SNI 3836:2013 tentang teh kering dalam kemasan yaitu memiliki standar kadar air maksimal $8,0 \%$.

\section{Kadar Ekstrak dalam Air}

Penetapan uji kadar ekstrak dalam air dilakukan untuk memberikan gambaran kadar (\%) senyawa suatu simplisia yang dapat larut dalam air (Departemen Kesehatan RI, 2000). Hasil penelitian mengenai pengaruh suhu dan waktu pengeringan terhadap kadar ekstrak dalam air teh celup herbal daun putri malu dapat dilihat pada Tabel 2.

Hasil sidik ragam menunjukkan bahwa interaksi antara suhu dan waktu pengeringan tidak berpengaruh nyata $(\mathrm{P}>0,05)$ terhadap kadar ekstrak dalam air teh celup herbal daun putri malu, sedangkan pengaruh masing-masing perlakuan suhu dan waktu pengeringan berpengaruh nyata $(\mathrm{P}<0,05)$ terhadap kadar ekstrak dalam air. Hasil 
penelitian menunjukkan bahwa kadar ekstrak dalam air tertinggi diperoleh pada perlakuan suhu pengeringan $60^{\circ} \mathrm{C}$ selama 150 menit dengan nilai rata-rata sebesar 20,80\%, sedangkan kadar ekstrak dalam air terendah diperoleh pada perlakuan suhu pengeringan $40^{\circ} \mathrm{C}$ selama 110 menit dengan nilai rata-rata sebesar 5,63\%. Penggunaan suhu tinggi dapat menyebabkan sifat bubuk menjadi higroskopis dan mudah menyerap air sehingga kelarutan bubuk menjadi besar (Purnomo et al., 2014). Winarno (2004) menyebutkan bahwa semakin lama proses pengeringan yang dilakukan menyebabkan jumlah air yang diuapkan dalam bahan pangan meningkat sehingga kadar ekstrak yang terukur semakin besar. Kadar ekstrak dalam air yang diperoleh dari penelitian ini belum memenuhi standar SNI 3836:2013 tentang teh kering dalam kemasan yaitu minimal $32 \%$.

Tabel 2. Pengaruh suhu dan waktu pengeringan terhadap nilai rata-rata kadar ekstrak dalam air (\% bk) teh celup herbal daun putri malu

\begin{tabular}{cccc}
\hline \multirow{2}{*}{ Suhu Pengeringan } & \multicolumn{3}{c}{ Waktu Pengeringan } \\
\cline { 2 - 4 } & 110 menit & 130 menit & 150 menit \\
\hline \multirow{2}{*}{$40^{\circ} \mathrm{C}$} & $5,63 \pm 0,11 \mathrm{a}$ & $8,72 \pm 0,27 \mathrm{a}$ & $(\mathrm{b})$ \\
& $(\mathrm{c})$ & $(\mathrm{c})$ & $18,29 \pm 1,12 \mathrm{a}$ \\
$50^{\circ} \mathrm{C}$ & $14,70 \pm 0,15 \mathrm{~b}$ & $15,60 \pm 0,45 \mathrm{~b}$ & $(\mathrm{a})$ \\
& $(\mathrm{b})$ & $(\mathrm{b})$ & $20,80 \pm 0,08 \mathrm{a}$ \\
$60^{\circ} \mathrm{C}$ & $18,83 \pm 0,06 \mathrm{a}$ & $20,38 \pm 1,53 \mathrm{a}$ & $(\mathrm{a})$ \\
\hline
\end{tabular}

Keterangan : Nilai rata-rata \pm standar deviasi $(n=2)$. Huruf yang sama di belakang nilai rata-rata pada baris yang sama atau di bawah nilai rata-rata pada kolom yang sama menunjukkan perlakuan berbeda tidak nyata $(\mathrm{P}>0,05)$

\section{Total Fenol}

Hasil sidik ragam menunjukkan interaksi antara suhu dan waktu pengeringan tidak berpengaruh nyata $(\mathrm{P}>0,05)$ terhadap total fenol teh celup herbal daun putri malu, begitu pun dengan masing-masing perlakuan suhu dan waktu pengeringan yang dilakukan dalam penelitian ini. Nilai rata-rata total fenol (mg GAE/g bk bahan) teh celup herbal daun putri malu dapat dilihat pada Tabel 3.

Tabel 3. Pengaruh suhu dan waktu pengeringan terhadap nilai rata-rata total fenol (mg GAE/g bk bahan) teh celup herbal daun putri malu

\begin{tabular}{cccc}
\hline \multirow{2}{*}{ Suhu Pengeringan } & \multicolumn{3}{c}{ Waktu Pengeringan } \\
\cline { 2 - 4 } $40^{\circ} \mathrm{C}$ & 110 menit & 130 menit & 150 menit \\
& $24,96 \pm 1,78 \mathrm{a}$ & $26,00 \pm 1,82 \mathrm{a}$ & $24,94 \pm 3,70 \mathrm{a}$ \\
$50^{\circ} \mathrm{C}$ & $(\mathrm{a})$ & $(\mathrm{a})$ & $(\mathrm{a})$ \\
& $25,19 \pm 3,82 \mathrm{a}$ & $26,23 \pm 2,64 \mathrm{a}$ & $25,00 \pm 3,09 \mathrm{a}$ \\
$60^{\circ} \mathrm{C}$ & $(\mathrm{a})$ & $(\mathrm{a})$ & $(\mathrm{a})$ \\
& $23,99 \pm 1,06 \mathrm{a}$ & $21,96 \pm 2,33 \mathrm{a}$ & $21,28 \pm 1,07 \mathrm{a}$ \\
Keterangan : Nilai rata-rata \pm standar deviasi (n=2). Huruf yang sama di belakang nilai rata-rata pada baris yang sama \\
atau di bawah nilai rata-rata pada kolom yang sama menunjukkan perlakuan berbeda tidak nyata (P>0,05)
\end{tabular}


Penurunan senyawa fenol yang terjadi pada perlakuan suhu $60^{\circ} \mathrm{C}$ disebabkan oleh degradasi senyawa fenolik selama pengeringan (Murtijaya dan Lim, 2007). Untuk melihat pengaruh pengeringan yang dilakukan, kandungan total fenol harus dihitung berdasarkan persentase kerusakan antara daun segar dan daun kering berdasarkan berat kering bahan (Said et al., 2013). Penelitian yang dilakukan oleh Das et al. (2014) menyebutkan bahwa kandungan total fenol daun segar putri malu sebesar 42,9 mg GAE/g. Apabila dihitung persentase kerusakan total fenol berdasarkan kandungan daun segarnya, kerusakan yang terjadi sebesar $41 \%$ untuk perlakuan suhu $40^{\circ} \mathrm{C}, 40 \%$ untuk perlakuan suhu $50^{\circ} \mathrm{C}$, dan $47 \%$ untuk perlakuan suhu $60^{\circ} \mathrm{C}$.

Adanya peningkatan total fenol pada perlakuan suhu $50^{\circ} \mathrm{C}$ disebabkan oleh meningkatnya kadar tanin terkondensasi karena polimerisasi flavonoid pada suhu tinggi (Harbourne et al., 2009). Rahmawati et al. (2013) mengatakan bahwa kandungan fenol akan terganggu oleh semakin tingginya suhu pengeringan sehingga jumlah total fenol akan mencapai puncak maksimum kemudian konstan dan cenderung mengalami penurunan. Penelitian serupa berkaitan dengan pengaruh suhu pengeringan terhadap total fenol juga penah dilakukan oleh Toit dan Joubert (1998) yang menemukan bahwa suhu pengeringan $40^{\circ} \mathrm{C}-70^{\circ} \mathrm{C}$ tidak berpengaruh terhadap total fenolik pada teh honeybush. Pada penelitian ini, perlakuan suhu $50^{\circ} \mathrm{C}$ selama 110 menit menghasilkan total fenol terbaik dengan nilai $25,19 \mathrm{mg}$ GAE/g bk bahan.

\section{Total Flavonoid}

Hasil sidik ragam menunjukkan bahwa interaksi antara suhu dan waktu pengeringan berpengaruh nyata $(\mathrm{P}<0,05)$ terhadap total flavonoid teh celup herbal daun putri malu. Nilai rata-rata total flavonoid (mg QE/g bk bahan) dapat dilihat pada Tabel 4. Berdasarkan Tabel 4, kadar total flavonoid teh celup herbal daun putri malu berkisar antara 12,85 mg QE/g-16,74 mg QE/g. Kadar total flavonoid tertinggi diperoleh pada perlakuan suhu pengeringan $50^{\circ} \mathrm{C}$ selama 130 menit yaitu sebesar 16,74 mg QE/g yang tidak berbeda nyata dengan perlakuan suhu $50^{\circ} \mathrm{C}$ selama 110 dan 150 menit, sedangkan kadar total flavonoid terendah diperoleh pada perlakuan suhu pengeringan $60^{\circ} \mathrm{C}$ selama 150 menit yaitu sebesar $12,85 \mathrm{mg} \mathrm{QE} / \mathrm{g}$.

Tabel 4. Pengaruh suhu dan waktu pengeringan terhadap nilai rata-rata total flavonoid (mg QE/g bk bahan) teh celup herbal daun putri malu

\begin{tabular}{cccc}
\hline \multirow{2}{*}{ Suhu Pengeringan } & \multicolumn{3}{c}{ Waktu Pengeringan } \\
\cline { 2 - 4 } & 110 menit & 130 menit & 150 menit \\
\hline $40{ }^{\circ} \mathrm{C}$ & $13,97 \pm 0,15 \mathrm{~b}$ & $14,78 \pm 0,22 \mathrm{a}$ & $14,46 \pm 0,24 \mathrm{ab}$ \\
& $(\mathrm{a})$ & $(\mathrm{b})$ & $(\mathrm{b})$ \\
$50^{\circ} \mathrm{C}$ & $16,07 \pm 1,51 \mathrm{a}$ & $16,74 \pm 0,75 \mathrm{a}$ & $15,80 \pm 0,12 \mathrm{a}$ \\
& $(\mathrm{a})$ & $(\mathrm{a})$ & $(\mathrm{a})$ \\
$60^{\circ} \mathrm{C}$ & $15,08 \pm 0,07 \mathrm{a}$ & $13,26 \pm 0,21 \mathrm{~b}$ & $12,85 \pm 0,19 \mathrm{~b}$ \\
& $(\mathrm{a})$ & $(\mathrm{c})$ & $(\mathrm{c})$ \\
\hline
\end{tabular}

Keterangan : Nilai rata-rata \pm standar deviasi $(n=2)$. Huruf yang sama di belakang nilai rata-rata pada baris yang sama atau di bawah nilai rata-rata pada kolom yang sama menunjukkan perlakuan berbeda tidak nyata $(\mathrm{P}>0,05)$ 
Hasil penelitian menunjukkan kadar total flavonoid mengalami peningkatan pada suhu $50^{\circ} \mathrm{C}$ kemudian mengalami penurunan pada suhu $60^{\circ} \mathrm{C}$ seiring waktu pengeringan yang semakin lama. Senyawa flavonoid adalah senyawa fenolik yang banyak ditemukan di dalam tumbuhan hijau yang banyak terkonsentrasi pada biji buah, kulit buah, kulit kayu, daun, dan bunga sehingga menurunnya total fenol diikuti dengan menurunnya total flavonoid (Miller, 1996). Penelitian yang dilakukan oleh Said et al. (2013) mengenai pengaruh suhu pengeringan $40^{\circ} \mathrm{C}-60^{\circ} \mathrm{C}$ pada daun Allium roseum juga menunjukkan hasil serupa di mana semakin tinggi suhu pengeringan yang digunakan, kadar flavonoid akan menurun akibat teroksidasi pada suhu panas. Menurut Lenny
(2006), senyawa flavonoid bersifat tidak tahan panas dan mudah teroksidasi pada suhu yang tinggi.

\section{Aktivitas Antioksidan Berdasarkan Nilai IC (50 $_{50}$}

Hasil sidik ragam menunjukkan bahwa interaksi antara suhu dan waktu pengeringan tidak berpengaruh nyata $(\mathrm{P}>0,05)$ terhadap nilai $\mathrm{IC}_{50}$ teh celup herbal daun putri malu. Suhu pengeringan berpengaruh nyata $(\mathrm{P}<0,05)$ terhadap nilai $\mathrm{IC}_{50}$ teh celup herbal daun putri malu sedangkan waktu pengeringan tidak berpengaruh nyata $(\mathrm{P}>0,05)$. Nilai rata-rata $\mathrm{IC}_{50}(\mathrm{ppm})$ berdasarkan berat kering teh celup herbal daun putri malu pada perlakuan suhu dan waktu pengeringan dapat dilihat pada Tabel 5.

Tabel 5. Pengaruh suhu dan waktu pengeringan terhadap rata-rata nilai $\mathrm{IC}_{50}(\mathrm{ppm})$ teh celup herbal daun putri malu

\begin{tabular}{cccc}
\hline \multirow{2}{*}{ Suhu Pengeringan } & \multicolumn{3}{c}{ Waktu Pengeringan } \\
\cline { 2 - 4 } & 110 menit & 130 menit & 150 menit \\
\hline \multirow{2}{*}{$40^{\circ} \mathrm{C}$} & $91,23 \pm 9,20 \mathrm{a}$ & $90,97 \pm 8,15 \mathrm{a}$ & $86,69 \pm 8,37 \mathrm{a}$ \\
& $(\mathrm{a})$ & $(\mathrm{a})$ & $(\mathrm{a})$ \\
$50^{\circ} \mathrm{C}$ & $74,45 \pm 0,93 \mathrm{a}$ & $70,55 \pm 5,72 \mathrm{a}$ & $71,17 \pm 6,13 \mathrm{a}$ \\
& $(\mathrm{a})$ & $(\mathrm{b})$ & $(\mathrm{a})$ \\
$60^{\circ} \mathrm{C}$ & $70,86 \pm 6,11 \mathrm{~b}$ & $77,48 \pm 1,25 \mathrm{ab}$ & $84,19 \pm 1,97 \mathrm{a}$ \\
& $(\mathrm{a})$ & $(\mathrm{ab})$ & (a) \\
\hline Ke & & &
\end{tabular}

Keterangan : Nilai rata-rata \pm standar deviasi $(\mathrm{n}=2)$. Huruf yang sama di belakang nilai rata-rata pada baris yang sama atau di bawah nilai rata-rata pada kolom yang sama menunjukkan perlakuan berbeda tidak nyata $(\mathrm{P}>0,05)$

Nilai $\mathrm{IC}_{50}$ teh celup herbal daun putri malu berkisar antara 70,55 ppm- 91,23 ppm. Teh celup herbal daun putri malu yang diberi perlakuan suhu pengeringan $50^{\circ} \mathrm{C}$ menghasilkan nilai $\mathrm{IC}_{50}$ sebesar 72,06 ppm yang tidak berbeda nyata dengan perlakuan suhu $60^{\circ} \mathrm{C}$ dan waktu pengeringan 110 , 130, dan 150 menit di mana hasil tersebut lebih tinggi dibandingkan teh celup herbal yang diberi perlakuan suhu $40^{\circ} \mathrm{C}$.
Hasil penelitian menunjukkan bahwa ada peningkatan nilai $\mathrm{IC}_{50}$ pada perlakuan suhu $50^{\circ} \mathrm{C}$ dengan lama waktu pengeringan 110, 130, dan 150 menit. Hal ini disebabkan karena total fenol dan total flavonoid pada perlakuan suhu $50^{\circ} \mathrm{C}$ mengalami peningkatan. Namun, pada perlakuan suhu $60^{\circ} \mathrm{C}$ nilai $\mathrm{IC}_{50}$ mengalami sedikit penurunan yang tidak signifikan akibat perlakuan suhu yang meningkat. Senyawa aktioksidan akan mudah 
terdegradasi jika terkena suhu tinggi dalam waktu yang lama. Hal ini dikarenakan senyawa antioksidan kehilangan kemampuan mendonorkan elektron untuk menetralkan senyawa-senyawa radikal (Patras et al., 2009). Pada penelitian ini, waktu pengeringan tidak berpengaruh nyata karena jaraknya yang terlalu pendek sehingga perbedaannya tidak dapat dilihat secara signifikan. Namun, suhu pengeringan berpengaruh nyata terhadap nilai $\mathrm{IC}_{50}$ yang terkandung di dalam teh celup herbal daun putri malu. Hal ini dikarenakan pemanasan yang cukup lama dan menggunakan suhu yang tinggi dapat menyebabkan penurunan aktivitas antioksidan (Andarwulan et al., 1996).

Menurut Molyneux (2004), $\mathrm{IC}_{50}$ merupakan konsentrasi suatu zat antioksidan yang dapat menghambat radikal bebas sebanyak 50\%. Teh celup herbal daun putri malu memiliki nilai $\mathrm{IC}_{50}$ kurang dari 100 ppm yang berarti memiliki sifat antioksidan kuat. Tingginya aktivitas antioksidan teh celup herbal daun putri malu dipengaruhi oleh kadar total fenol dan flavonoid yang merupakan senyawa bioaktif yang berperan sebagai antioksidan (Yondra et al., 2014). Flavonoid merupakan senyawa fenolik yang bersifat sebagai antioksidan, sehingga semakin tinggi total flavonoidnya, maka semakin tinggi aktivitas antioksidannya (Zuhra et al., 2008).

\section{Evaluasi Sensori}

Evaluasi sensori yang dilakukan terhadap teh celup herbal daun putri malu meliputi warna, aroma, rasa, dan penerimaan keseluruhan dengan menggunakan metode uji skoring dan hedonik. Uji skoring digunakan untuk mengetahui besarnya perbedaan kualitas dan intensitas sifat tertentu pada beberapa produk sejenis dengan menggunakan skala angka satu sebagai niai terendah dan tujuh sebagai niai tertinggi. Sedangkan uji hedonik digunakan untuk mengetahui tingkat kesukaan dari suatu produk (Soekarto, 1990).

Tujuan dilakukannya evaluasi sensori yaitu untuk mengetahui tingkat kesukaan konsumen terhadap teh celup herbal daun putri malu. Uji skoring dilakukan terhadap rasa, sedangkan uji hedonik dilakukan terhadap aroma, warna, rasa, dan penerimaan keseluruhan. Nilai rata-rata kesukaan panelis terhadap warna, aroma, rasa,dan penerimaan keseluruhan dan skor rasa pahit seduhan teh celup herbal daun putri malu dapat dilihat pada Tabel 6 .

\section{Warna}

Warna merupakan salah satu aspek mutu yang dapat mempengaruhi penilaian panelis terhadap suatu produk. Hasil sidik ragam menunjukkan bahwa perlakuan suhu dan waktu pengeringan tidak berpengaruh nyata $(\mathrm{P}>0,05)$ terhadap kesukaan panelis pada warna seduhan teh celup herbal daun putri malu. Berdasarkan hasil uji hedonik terhadap warna seduhan teh, rata-rata panelis memberikan nilai 5,32-5,60 dengan kriteria agak suka. Warna seduhan teh celup herbal daun putri malu berwarna hijau muda dan tidak terlihat perbedaan yang nyata pada setiap perlakuan. 
Tabel 6. Nilai rata-rata kesukaan dan skor rasa pahit seduhan teh celup herbal daun putri malu dengan suhu dan waktu pengeringan berbeda

\begin{tabular}{cccccc}
\hline Perlakuan & Warna & Aroma & Rasa & $\begin{array}{c}\text { Penerimaan } \\
\text { Keseluruhan }\end{array}$ & $\begin{array}{c}\text { Skor Rasa } \\
\text { Pahit }\end{array}$ \\
\hline T1W1 & $5,60 \pm 1,23 \mathrm{a}$ & $5,12 \pm 0,97 \mathrm{a}$ & $4,80 \pm 1,16 \mathrm{a}$ & $4,68 \pm 1,22 \mathrm{a}$ & $3,72 \pm 0,61 \mathrm{ab}$ \\
T1W2 & $5,44 \pm 1,30 \mathrm{a}$ & $5,08 \pm 0,86 \mathrm{a}$ & $4,68 \pm 1,22 \mathrm{a}$ & $4,80 \pm 1,16 \mathrm{a}$ & $3,84 \pm 0,47 \mathrm{a}$ \\
T1W3 & $5,44 \pm 1,23 \mathrm{a}$ & $5,04 \pm 0,94 \mathrm{a}$ & $4,68 \pm 1,41 \mathrm{a}$ & $4,60 \pm 1,08 \mathrm{a}$ & $3,60 \pm 0,58 \mathrm{ab}$ \\
T2W1 & $5,36 \pm 1,22 \mathrm{a}$ & $4,80 \pm 1,04 \mathrm{a}$ & $4,76 \pm 1,23 \mathrm{a}$ & $4,92 \pm 0,95 \mathrm{a}$ & $3,48 \pm 0,59 \mathrm{ab}$ \\
T2W2 & $5,36 \pm 1,00 \mathrm{a}$ & $5,12 \pm 0,97 \mathrm{a}$ & $4,92 \pm 1,29 \mathrm{a}$ & $5,12 \pm 0,97 \mathrm{a}$ & $3,72 \pm 0,54 \mathrm{ab}$ \\
T2W3 & $5,40 \pm 1,04 \mathrm{a}$ & $5,20 \pm 0,96 \mathrm{a}$ & $4,92 \pm 1,26 \mathrm{a}$ & $4,84 \pm 0,94 \mathrm{a}$ & $3,60 \pm 0,71 \mathrm{ab}$ \\
T3W1 & $5,32 \pm 1,07 \mathrm{a}$ & $4,96 \pm 1,27 \mathrm{a}$ & $4,60 \pm 1,26 \mathrm{a}$ & $4,64 \pm 1,19 \mathrm{a}$ & $3,32 \pm 0,75 \mathrm{~b}$ \\
T3W2 & $5,52 \pm 1,09 \mathrm{a}$ & $5,00 \pm 1,32 \mathrm{a}$ & $5,00 \pm 1,41 \mathrm{a}$ & $4,96 \pm 1,02 \mathrm{a}$ & $3,36 \pm 0,81 \mathrm{~b}$ \\
T3W3 & $5,60 \pm 1,96 \mathrm{a}$ & $4,68 \pm 1,31 \mathrm{a}$ & $4,88 \pm 1,51 \mathrm{a}$ & $4,64 \pm 0,95 \mathrm{a}$ & $3,32 \pm 0,80 \mathrm{~b}$ \\
\hline
\end{tabular}

Keterangan : Nilai rata-rata \pm standar deviasi $(\mathrm{n}=2)$. Huruf yang sama di belakang nilai rata-rata pada kolom yang sama menunjukkan perlakuan berbeda tidak nyata $(\mathrm{P}>0,05)$

Nilai hedonik: $1=$ Sangat Tidak Suka, $2=$ Tidak Suka, $3=$ Agak Tidak Suka, 4= Biasa, $5=$ Agak Suka, $6=$ Suka, $7=$ Sangat Suka

Nilai skoring: $1=$ Sangat Pahit, $2=$ Pahit, $3=$ Agak Pahit, 4= Tidak Pahit

\section{Aroma}

Aroma dari suatu produk makanan atau minuman memberikan peranan penting dalam sebuah penilaian produk. Apabila sebuah produk memiliki aroma yang khas, maka produk dikatakan baik (Winarno, 2004). Hasil sidik ragam menunjukkan bahwa perlakuan suhu dan waktu pengeringan tidak berpengaruh nyata $(\mathrm{P}>0,05)$ terhadap kesukaan panelis pada aroma seduhan teh celup herbal daun putri malu.

Berdasarkan hasil uji hedonik terhadap aroma seduhan teh, rata-rata panelis memberikan nilai 4,68-5,20 dengan kriteria biasa hingga agak suka. Hal ini dikarenakan aroma seduhan teh celup herbal daun putri malu yang beraroma khas daun. Penelitian yang dilakukan oleh Vismayaviswan et al. (2018) menyebutkan bahwa tanaman putri malu memiliki komponen minyak atsiri yang memberikan aroma khas tanaman.
Rasa

Hasil sidik ragam menunjukkan bahwa perlakuan suhu dan waktu pengeringan berpengaruh nyata $(\mathrm{P}<0,05)$ terhadap rasa seduhan teh celup herbal daun putri malu yang diuji secara skoring. Skor rata-rata rasa seduhan teh celup herbal daun putri malu berkisar antara 3,32-3,84 dengan kriteria agak pahit. Namun, semakin tinggi suhu pengeringan intensitas rasa pahitnya semakin menurun akibat kerusakan tanin pada suhu tinggi. Tanin merupakan senyawa yang dapat menentukan kualitas teh yang berkaitan dengan warna, rasa, dan aroma pada teh. Adanya senyawa tanin dalam bahan makanan dapat memberikan rasa pahit atau sepat (Sekarini, 2011).

Hasil sidik ragam menunjukkan bahwa perlakuan suhu dan waktu pengeringan berpengaruh tidak nyata $(\mathrm{P}>0,05)$ terhadap kesukaan panelis pada rasa seduhan teh celup herbal daun putri malu. Nilai rata-rata yang diberikan oleh panelis berkisar antara 4,60-5,00 dengan kriteria biasa hingga agak suka. Hal ini 
menunjukkan bahwa rasa yang dihasilkan oleh seduhan teh celup herbal daun putri malu masih dapat diterima oleh panelis.

\section{Penerimaan Keseluruhan}

Penerimaan keseluruhan merupakan penilaian terakhir yang merupakan hasil dari beberapa penilaian terhadap beberapa parameter seperti warna, aroma, dan rasa yang bertujuan untuk melihat tingkat kesukaan panelis secara keseluruhan dari produk teh celup herbal daun putri malu.

Hasil sidik ragam menunjukkan bahwa perlakuan suhu dan waktu pengeringan tidak berpengaruh nyata $(\mathrm{P}>0,05)$ terhadap penerimaan keseluruhan seduhan teh celup herbal daun putri malu. Nilai rata-rata penerimaan keseluruhan seduhan teh celup herbal daun putri malu berkisar antara 4,60-5,12 dengan kriteria biasa hingga agak suka. Hal ini menunjukkan bahwa panelis dapat menerima produk teh celup herbal daun putri malu dari segi warna, aroma, dan rasa.

\section{KESIMPULAN}

Berdasarkan hasil dari penelitian, dapat diambil kesimpulan bahwa interaksi suhu dan waktu pengeringan berpengaruh nyata terhadap total flavonoid, namun berpengaruh tidak nyata terhadap kadar air, kadar ekstrak dalam air, total fenol, dan nilai $\mathrm{IC}_{50}$. Suhu dan waktu pengeringan berpengaruh nyata terhadap kadar air dan nilai $\mathrm{IC}_{50}$, sedangkan suhu dan waktu pengeringan berpengaruh nyata terhadap kadar ekstrak dalam air dan skor rasa pahit. Hasil penelitian menunjukkan bahwa suhu pengeringan $50^{\circ} \mathrm{C}$ selama 110 menit merupakan suhu dan waktu pengeringan terbaik untuk menghasilkan teh celup herbal daun putri malu dengan karakteristik sebagai berikut: kadar air 6,50\%; kadar ekstrak dalam air 14,70\%; total fenol 25,19 mg GAE/g bk bahan; total flavonoid 16,07 mg QE/g bk bahan; nilai $\mathrm{IC}_{50}$ sebesar 74,45 ppm; warna, aroma, dan rasa agak disukai; penerimaan keseluruhan biasa; serta rasa agak pahit.

\section{DAFTAR PUSTAKA}

Andarwulan, N., C.H. Wijaya, dan D.T. Cahyono. (1996). Aktivitas Antioksidan dari Daun Sirih (Piper betle L.). Buletin Teknologi dan Industri Pangan. 7: 29-37.

Angraiyati, D., dan F. Hamzah. (2017). Lama Pengeringan pada Pembuatan Teh Herbal Daun Pandan Wangi (Pandanus amarylifolius Roxb.,) terhadap Aktivitas Antioksidan. JOM Faperta. 4(1): 1-12.

Anonim. (1985). Cara Pembuatan Simplisia. Jakarta: Dirjen Pengawasan Obat dan Makanan.

Anonim. (1996). Petunjuk Pengujian Organoleptik dan atau Sensoris (SNI 01-2346-2006). Jakarta: Badan Standarisasi Nasional.

Anonim. (2000). Parameter Standar Umum Ekstrak Tumbuhan Obat. Jakarta: Departemen Kesehatan Republik Indonesia.

Anonim. (2013). Standar Nasional Indonesia (SNI) 3836:2013 Syarat Mutu Teh Kering dalam Kemasan. Jakarta: Dewan Standar Nasional Indonesia-DSN.

AOAC. (2005). Official Methods of Analysis. Association of Official Analytical Chemists. Washington: Benjamin Franklin Station.

Das, K., M. Yasin, N.U. Mahbub, M.S. Islam, dan N. Mahbuba. (2014). Evaluation of Antioxidant and Cytoxic Activity of Methanolic Extract of Mimosa pudica leaves. The Pharma Innovation-Journal. 3(4): 32-36.

Toit, J.D., dan E. Joubert. (1998). Effect of Drying Conditions on The Quality of Honeybush Tea 
(Cyclopia). Journal of Food Processing and Preservation. 22: 493-507.

Fajriah, S., Darmawan, Sundowo, dan Artanti. (2007). Isolasi Senyawa Antioksidan dari Ekstrak Etil Asetat Daun Benalu (Dendrophthoe pentandra L. Miq) yang Tumbuh pada Inang Lobi-lobi. Jurnal Kimia Indonesia. 2(1): 17-20.

Fitriana, A., N. Harun dan Yusmarini. (2017). Mutu Teh Herbal Daun Keji Beling dengan Perlakuan Lama Pengeringan. SAGU. 16(2): 34-41.

Garcia, C.A., G. Gavino, M.B. Mosqueda, P. Hevia, dan V.C. Gavino. (2007). Correlation of Tocopherol, Tokotrienol, $\gamma$-oryzanol and Total Polyphenol Content in Rice Bran with Different Antioxidant Capacity Assays. Food Chemistry. 102: 1228-1232.

Ghasemzadeh, A., V. Omidvar, dan H.Z.E. Jaafar. (2012). Polyphenolic Content and Their Antioxidant Activity in Leaf Extract Of Sweet Potato (Ipomoea batatas). Journal of Medicinal Plant Research. 6(15): 2971-2976.

Gomez, K.A., dan A.A. Gomez. (1995). Prosedur Statistik Untuk Penelitian Pertanian. Jakarta: UI Press.

Guntarti, A., J. Annisa, M. Mughniy, dan F. Rizqi. (2017). Effect of Regional Variation on The Total Flavonoid Level of Ethanol Extract of Mangosteen (Garcinia mangostana) Peels. Indonesian Journal of Medicine and Health. 8(2): 136-143.

Hanani, E., A. Munim, dan R. Sekarini. (2005). Identifikasi Senyawa Antioksidan dalam Spons Callyspongia sp. dari Kepulauan Seribu. Majalah Ilmu Kefarmasian. 2(3): 127133.

Harbourne, N., E. Marete, J.C. Jacquier, dan D. O'Riordan. (2009). Effect of Drying Methods on The Phenolic Constituents of Meadowsweet (Filipendula ulmaria) and Willow (Salix alba). LWT-Food Science and Technology. 42: 1468-1473.

Hartati, S.Y., dan Taryono. (2013). Khasiat kunyit sebagai Obat Tradisional dan Manfaat Lainnya. Warta Penelitian dan Pengembangan Tanaman Industri. 19(2): 5-9.

Lenny, S. (2006). Bahan Ajar Metode Fitokimia. Surabaya: FMIPA, Universitas Airlangga.
Lutony, T.L., dan y. Rahmayati. (1994). Produksi dan Perdagangan Minyak Atsiri. Jakarta: Penebar Swadaya.

Miller, A.L. (1996). Antioxidant Flavonoids: Structure, Function, and Clinical Usage. Alt Med Rev 1:103 - 111.

Mohan, S.M., B. Pandey, dan S.G. Rao. (2015). Phytochemical Analysis and Uses of Mimosa pudica Linn. in Chhattisgarh. IOSR-JESTFT. 1(3): 1-4.

Molyneux, P. (2004). The Use of The Stable Free Radical Diphenylpicryl-Hydrazyl (DPPH) for Estimating Antioxidant Activity. Songklanakarin J. Sci. Technol. 26(2): 21121.

Muhammad, G., M.A. Hussain, I. Jantan, dan A.N.A. Bukhari. (2016). Mimosa pudica L., A High-Value Medicinal Plant as A Source of Bioactives for Pharmaceuticals. Comprehensive Reviews in Food Science and Food Safety. 15: 303-315.

Murtijaya, L., dan Y.Y. Lim. (2007). Antioxidant Properties of Phylanthus amarus Extracts as Affected by Different Drying Methods. LWTFood Science and Technology. 40: 16641669.

Patin, E. W., M. A. Zaini, dan Y. Sulastri. (2018). Pengaruh Variasi Suhu Pengeringan Terhadap Sifat Fisiko Kimia Teh Daun Sambiloto (Andrographis paniculata). Jurnal Ilmu dan Teknologi Pangan. 4(1): 251-258.

Patras, A., N. Brunton, S.D. Pieve, F. Butler, dan G. Downey. (2009). Effect of Thermal and High Pressure Processing on Antioxidant Activity and Instrumental Colour of Tomato and Carrot Purees. Innovative Food Science and Emerging Technologies. 10: 16-22.

Purnomo, W., L.U. Khasanah, dan R.B.K. Anandito. (2014). Pengaruh Ratio Kombinasi Maltodekstrin, Karagenan dan Whey Terhadap Karakteristik Mikroenkapsulan Pewarna Alami Daun Jati (Tectona grandis L.F.). Jurnal Aplikasi Teknologi Pangan. 3(3): 99-107.

Rahmawati, N., A. Fernando, dan Wachyuni. (2013). Kandungan Fenolik dan Aktivitas Antioksidan Ekstrak Daun Gambir Kering Uncaria Gambir (Hunter) ROXB). Jurnal Indonesia Chemia Acta. 4(1): 1-6.

Said, L.B.H., H. Najjaa, M. Neffati, dan S. Bellagha. (2013). Color, Phenolic and 
Antioxidant Characteristic Changes of Allium Roseum Leaves During Drying. Journal of Food Quality. 36: 403-410.

Sekarini, G.A. (2011). Kajian Penambahan Gula dan Suhu Penyajian Terhadap Kadar Total Fenol, Kadar Tanin (Katekin) dan Aktivitas Antioksidan pada Minuman Teh Hijau (Camellia sinensis L.) Skripsi. Surakarta: Universitas Sebelas Maret.

Soekarto. (1990). Penilaian Organoleptik Untuk Industri Pangan dan Hasil Pertanian. Jakarta: Bhatara Aksara.

Topuz, A., C. Dincer, M. Torun, I. Tontul, H.S. Nadeem, A. Haznedar dan F. Özdemir. (2014). Physicochemical Properties of Turkish Green Tea Powder: Effects of Shooting Period, Shading, and Clone. Turkish Journal of Agriculture and Forestry. 38: 233241.

Vismayaviswan, T.K., J. Dharani, R. Sripathi, dan S. Ravi. (2019). Composition of The Essential Oil from Mimosa pudica Linn. Asian Journal of Pharmaceutical and Clinical Research. 12(3): 170-172.

Winarno, F. G. (2004). Kimia Pangan dan Gizi. Jakarta: Gramedia Pustaka Utama.

Winarsi, Hery. (2011). Antioksidan Alami dan Radikal Bebas. Yogyakarta: Kanisius.

Yondra, A.D., C. Jose dan H.Y. Teruna. (2014). Total Fenolik, Flavonoid serta Aktivitas Antioksidan Ekstrak $N$-Heksana, Diklorometan dan Metanol Amaranthus spinosus L EM5-Bawang Putih. Journal FMIPA. 1(2): 359-369.

Yudana, I.G.A. (2004). Mengenal ragam dan manfaat teh. http://www.indomedia.com/intisari/1998, teh. html. Diakses tanggal 2 Januari 2019.

Zhang, J., K. Yuan, W. Zhou, J. Zhou, dan P. Yang. (2011). Studies on the active components and antioxidant activities of the extracts of Mimosa pudica Linn. from southern China. Pharmacognosy Magazine. 7(25): 35-39.

Zuhra, C.F., J. Tarigan dan H. Sihotang. (2008). Aktivitas Antioksidan Senyawa Flavonoid dari Daun Katuk (Sauropus androgunus (L) Merr.). Jurnal Biologi Sumatera. 3(1): 7-10. 